\title{
A Critical Role of the Student Teaching on Instructional Beliefs: An Example of Early Childhood Student and Cooperating Teachers
}

\author{
By Nesrin Islkoglu Erdogan*
}

\begin{abstract}
This study investigated student teachers' instructional beliefs over the course of student teaching. This study also examined the relationship between the beliefs of student teachers and their cooperating teachers. Participants of the study were 75 student teachers and 35 cooperating teachers. Data were gathered through Teacher Beliefs Survey, which were administered at the beginning and at the end of the student teaching period. Findings showed that the constructivist beliefs of the participant student teachers increased during the student teaching period. Cooperating teachers hold more traditional beliefs than student teachers. The implications of these results are discussed in relation to the literature.
\end{abstract}

\section{Introduction}

Teacher beliefs are defined as a set of personal conceptual constructs that signify to its holder a reality (Fang, 1996; Pajares, 1992). Beliefs are among the most important indicators of the decisions people make throughout their lives (Bandura, 1986). Teacher beliefs influence their decision making in the classroom and drive their instructional pedagogy (Fang, 1996; Pajares, 1992; Richardson, 1996). Researchers claim that early childhood teachers' beliefs are among the most important predictors of their classroom behaviors and practices (Buchanan, Burts, Bidner, White \& Charlesworth, 1998; Vartuli, 1999). In a meta-analyses study, Trivette, Dunst, Hamby and Meter (2012) find a relationship between early childhood practitioner belief appraisals and their adoption and use of innovative and recommended practices. Teacher beliefs are formed as a result of various factors such as educational experience, previous experience, classroom experience and reflection (Cummings, Cheek \& Lindsey, 2004).

The teacher education programs play a critical role in offering educational and classroom experiences for student teachers which help them to construct instructional beliefs. In particular, teacher education programs aim to offer a concrete theoretical base and teaching skills for student teachers. At these programs, teacher candidates learn about educational theories and teaching methods. It is expected that student teachers construct their own teaching conceptions through combining theoretical knowledge and practical

*Associate Professor, Pamukkale University, Turkey. 
experience. Providing as it does an environment for institutional socialization and teaching experience, student teaching is often viewed as the most powerful part of teacher education (Richardson, 1996).

The importance of student teaching for new teachers is vital and student teaching or internship experience is a central component of many teacher education programs (Rozelle \&Wilson, 2012). As a key part of teacher education programs, student teaching experience contributes to student teachers' professional learning. Research studies have shown that student teachers improve significantly in preparing, conducting and post-processing lessons and their attitudes toward students become more open during student teaching (Edwards, \& Protheroe, 2003; Hascher, Cocard \& Moser, 2004). Student teaching is seen as a significant factor in increasing teaching competence and providing experience in working with young children (Lin, Hazaereesighn, Taylor, Gorrell \& Carlson, 2001). The quality of student teaching has significant and positive effects on student teachers' professional development (Ronfeldt \& Reininger, 2012). Student teachers' personal characteristics, supervisors' support and quality of the school environment and learning experiences influence the process of student teaching (Caires \& Almeida, 2005). These factors sometimes can prevail over the teaching skills developed in pre-service course work and may lead to the development of beliefs substantially different from those held prior to beginning teaching (Smith, 1997). The development and learning of student teachers may not take the direction intended by teacher education programs during student teaching. Student teaching tends to move toward traditional styles of teaching away from reform minded methods and strategies promoted in teacher education programs (Rozelle \&Wilson, 2012).

Research studies that investigated the influences of student teaching on student teachers' beliefs have reported various results. A considerable body of research has suggested beliefs stayed stable over the course of student teaching. In her review study Kagan (1992) argued that teacher beliefs appear to be relatively stable and resistant to change and changes in teacher beliefs generally result from student teachers' actual practices rather than university course work. Others argued that student teachers' beliefs are altered and challenged as they interact with students, experienced colleagues and their peers (Levin, Hammer \& Coffey 2009). Through focusing and analyzing students' learning initial teacher education courses can help develop such skills so the student teachers can continue to learn from their own practice, and its impact upon student learning, throughout their careers (Hiebert et al., 2007).

The change in student teacher beliefs is a slow and difficult process (Brownlee, Purdie, \& Boulton-Lewis, 2001) and may be related to various factors including course work, student teaching and cooperating teachers. Implementing intervention courses found relatively effective for creating changes in student teacher beliefs. College courses to teach constructivist teaching methods changed student teachers' beliefs in that direction (DiPietro, 2004; Isikoglu, 2008; Pankratius \& Young, 1995). An early childhood teacher education program evaluation study revealed that students who are further 
along in the program hold more developmentally appropriate beliefs and more child-centered views of children than students not enrolled in the teacher preparation program or students who are just beginning the program (ScottLittle, LaParo \& Weisner , 2001). Moreover, the influences of cooperating teachers are recognized in research studies. Wooley, Wooley \& Hosey, (1999) examined the impact of student teaching on student teachers' constructivist and behaviorist beliefs. They revealed that student teachers' beliefs were changed as result of the influence of their cooperating teachers through modeling, giving feedback and encouraging them to take risks. Other studies also recognized student teaching and cooperating teachers as the most important influence on student teachers' beliefs ( $\mathrm{Su}, 1992)$. In a recent ethnographic study, Rozelle \&Wilson (2012) found that teaching practices were strongly influenced by the cooperating teachers and student teachers attempted to reenact lessons they witnessed their cooperating teachers teach. As various research results described above, creating a change in student teachers' beliefs is intricate and influenced by diverse sources including student teaching and cooperating teachers.

In relation to early childhood teacher education programs, pre-existing beliefs about teaching, their previous experiences as a student, their personal life experiences and their formal knowledge were sources of student teacher beliefs (Richardson, 1996). Considering the dominance of traditional instruction in schools, student teachers tend to enter these teacher education programs already holding traditional beliefs (Wooley et al., 1999). Traditionally, the Turkish early childhood curriculum was derived from behaviorist pedagogies and teacher-centered practices were dominant in these schools. Recently, The Ministry of National Education has attempted to change the national early childhood education curriculum in 2006 and 2012. The renewed early childhood education curriculum encourages teachers to adopt child-centered and constructivist practices (MEB, 2012). Therefore, teacher education programs attempt to shift pre-service teachers away from traditional beliefs and guide them to adopt more constructivist beliefs. For this reasons, this study aims to closely examine the changes in student teacher beliefs as result of student teaching. In particular, this study explores constructivist and traditional beliefs of student teachers and their cooperating teachers.

\section{Method}

\section{Setting}

The study was conducted at the early childhood education program of Pamukkale University in Turkey. Early childhood education is a four-year full time Bachelor of Education degree program. The program consists of general culture courses (history, literature, and philosophy), general education requirements (teaching methods, classroom management, planning and evaluation), professional education courses (child development, play, parent education, and special education), and content area method courses (language, 
science, mathematics, music and art). During their four year training, students have both theoretical and practical courses. Within these courses the constructivist philosophy and constructivist teaching methods are taught to the students.

The student teaching course is offered in the final year of the program. Before student teaching, the program has a field experience in which students observe various early childhood educational settings and teach sample early childhood activities. During the student teaching, the students are required to complete a full day or half day 15-week teaching experience at either preschools or kindergartens. They are required to plan and deliver daily early childhood activities. Prior to implementing activities, student teachers share their daily plans with both university supervisors and cooperating teachers and receive individual feedback. Weekly reflective journals describing the experiences, thoughts and beliefs are kept by the student teachers. Additionally, bi-weekly seminars are conducted at the university and the student teachers share and discuss their field experiences with their classmates and university supervisors. Throughout the course, the student teachers are in contact with two supervisors. One is the university supervisor whose task is to observe teaching experiences, give feedback and conduct bi-weekly seminars. The other is the cooperating teacher whose role includes supporting, observing and giving feedback for student teachers.

\section{Participants}

For this study, all fourth year students who enrolled in student teaching course were informed of and invited to participate in the study. Additionally, they informed that participation was voluntary and had no effect on their grades. A total of 75 student teachers filled and returned the surveys, yielding a response rate of $69 \%$. At the end of the 15 -week teaching placement the survey was administered to the same students. These participant student teachers were predominately female $(92 \%)$ and their average age was 21.89 years old (SD= 1.7). Approximately $82 \%$ of the student teachers were placed in public early childhood classrooms, while $18 \%$ were placed in private early childhood classrooms for student teaching. All of the student teachers had a single placement for the entire semester.

Furthermore, cooperating teachers of the student teachers were invited to participate in this study. Thirty five early childhood teachers who supervised these student teachers were included in this study. All of the cooperating teachers were female and their average age was 36.12 years old and their average teaching experience was 15.18 years.

\section{Measures}

To assess student teachers' and cooperating teachers' instructional beliefs, they were asked to complete the Teacher Beliefs Survey (TBS). Survey statements were developed from the position statement on developmentally appropriate practice for 4-and 5 year-old children published by the National Association for the Education of Young Children (NAEYC). From the 
NAEYC guidelines (Bredekamp, 1993) constructivist and traditional statements were developed. Initially, forty-six statements of constructivist and traditional practice were derived from the DAP guidelines. Each item was on a four-point Likert-type scale $(1=$ strongly disagree, $2=$ disagree, $3=$ agree and 4 = strongly agree). Use of a four point scale resulted in a forced choice response in either the constructivist or traditional direction, with no room for a neutral response (Smith, 1997).

Three curriculum specialists were asked to evaluate the content validity for the items. They used a four-point scale $(1=$ Weakly Represents to $4=$ Strongly Represents) to evaluate the content representativeness of the items. A minimum value of 2.0 was used as the decision rule for retaining acceptable items. The wording of some items was also adjusted on the feedback recommendation of curriculum specialists. Some of the items were removed from the survey due to cultural differences such as "psychometric tests are used as the sole criterion to prohibit entrance to the program." The survey was then applied to a convenience sample including 30 pre-service teachers. Using the SPSS program, the reliability of pre-service teacher responses to individual items and to the two scales was examined on the basis of item-total correlations and coefficient alphas. At the end of this procedure, sixteen items of the constructivist scale and sixteen items of the traditional scales were retained and randomly distributed in the survey.

\section{Reliability and Validity of the Instrument}

The Cronbach Alpha coefficients for the overall and sub scales: "traditional beliefs", and "constructivist beliefs" were calculated and tabulated. The internal consistency estimate (Cronbach's Alpha) for the constructivist scale was 0.83 , for the traditional scale was 0.74 and for total scale was 0.75 .

In order to establish construct validity of the instrument, an exploratory factor analysis was used to determine the number of factors underlying the 32 questions. Initial factor analysis revealed nine-factor solution which explained $61.02 \%$ of the total variance. Later, two-factor solution was tried and that was explained $25.90 \%$ of the total variance. Loadings of items on each factor are presented in Table 1. With a cutoff correlation of 0.3 (i.e. factor loading criterion) as an acceptable minimum loading value was used. The TBS examined the pre-service teachers' instructional beliefs with a total of thirtytwo items. The traditional scale items were reverse coded. The total score was calculated by adding each subscale score. 
Table 1. TBS Items and Factor Loadings

\begin{tabular}{|c|c|c|}
\hline \multirow[b]{2}{*}{ Items } & \multicolumn{2}{|c|}{ Component } \\
\hline & Constructivist & Traditional \\
\hline 1. Program should be determined based on children's age. & 013 & ,331 \\
\hline 2. Instruction should be divided into subject areas. &,- 155 & 444 \\
\hline $\begin{array}{l}\text { 3. Experiences are provided that meet children's needs } \\
\text { and stimulate learning in all development areas. }\end{array}$ & ,348 & ,003 \\
\hline $\begin{array}{l}\text { 4. Children select their own activities among a variety of } \\
\text { learning areas. }\end{array}$ & ,414 &, 116 \\
\hline $\begin{array}{l}\text { 5. Materials should be real and relevant to the children's } \\
\text { own life experiences. }\end{array}$ & ,342 & 006 \\
\hline 6. Teachers frequently use rewards to motivate children. & ,034 & ,389 \\
\hline $\begin{array}{l}\text { 7. Work sheets, flash cards and similar materials are used } \\
\text { to teach cognitive skills. }\end{array}$ & 000 &, 424 \\
\hline $\begin{array}{l}\text { 8. Children are expected to be physically and mentally } \\
\text { active and interact with each other. }\end{array}$ &, 535 &,- 120 \\
\hline $\begin{array}{l}\text { 9. Child's progress is compared to other children's } \\
\text { progress. }\end{array}$ &,- 186 &, 522 \\
\hline $\begin{array}{l}\text { 10. Assessment of children's progress should be based on } \\
\text { teacher observations. }\end{array}$ & ,435 &, 269 \\
\hline $\begin{array}{l}\text { 11. Teachers' main role is to teach children knowledge } \\
\text { and skills. }\end{array}$ &, 112 &, $\mathbf{5 0 3}$ \\
\hline 12. Children should gain self-control skills. &, 544 & 052 \\
\hline $\begin{array}{l}\text { 13. Various activities (science, language, art etc.) are } \\
\text { integrated in order to accomplish teaching goals. }\end{array}$ &, $\mathbf{5 3 0}$ &, 014 \\
\hline $\begin{array}{l}\text { 14. Curriculum is responsive to children's individual } \\
\text { differences in ability and interests. }\end{array}$ &, 595 &,- 014 \\
\hline $\begin{array}{l}\text { 15. Curriculum mainly focuses on the children's } \\
\text { intellectual development. }\end{array}$ & ,132 &, 525 \\
\hline $\begin{array}{l}\text { 16. Children are encouraged to work in individually, } \\
\text { small and large group activities }\end{array}$ & ,606 &,- 208 \\
\hline 17. Teaching materials should be abstract and symbolic. & , 101 &, $\mathbf{5 0 2}$ \\
\hline $\begin{array}{l}\text { 18. Teacher's main role is scaffolding and guiding } \\
\text { children. }\end{array}$ &, 515 &,- 051 \\
\hline $\begin{array}{l}\text { 19. Children's natural curiosity is used to motivate them } \\
\text { to become involved in learning activities. }\end{array}$ & ,630 &,- 152 \\
\hline $\begin{array}{l}\text { 20. Children should have individual spaces and they } \\
\text { should quietly study. }\end{array}$ &,- 146 & ,379 \\
\hline $\begin{array}{l}\text { 21. Children are led to learn their own individual learning } \\
\text { pace. }\end{array}$ & ,498 & 045 \\
\hline 22. Standard test are used to measure children's progress &,- 236 & ,353 \\
\hline 23. Teachers use stickers and points to motivate children. & ,289 & ,451 \\
\hline $\begin{array}{l}\text { 24. Teachers communicate with parents through formal } \\
\text { conferences. }\end{array}$ &, 144 & ,432 \\
\hline $\begin{array}{l}\text { 25. Teachers make sure that children sit still and be quite } \\
\text { in the classroom. }\end{array}$ & 043 &, 564 \\
\hline $\begin{array}{l}\text { 26. Children learn through interacting with and observing } \\
\text { people and materials. }\end{array}$ &, 528 &,- 110 \\
\hline
\end{tabular}


27. Teachers frequently interact with parents both formal and informal meetings.

, 570 $-, 028$

28 . Whole group activities dominate daily routine.

29. Teachers expect that each child has own way of leaning.

30. Children learn through working with workbooks, drawing, ditto sheets and similar materials.

31. Teachers expect that children actively involved in activities and interact with each other.

32. Based on children's age and grade level teachers can determine children's progress.

$\%$ of variance explained (overall, 25,90)
, 107

, 408

, 518

$-, 084$

$-, 114$

, 645

, 519

, 075

$-, 055$

, 469

\section{Data Analysis}

Descriptive statistics were used to describe the participants' demographic data. The means for each student and cooperating teacher on constructivist and traditional subscales and total TBS were calculated. The paired t-tests were used to examine differences between pre and post survey scores and independent t-tests were used to identify differences between student teachers' and cooperating teachers' survey scores.

\section{Results}

\section{Changes in Student Teachers' Beliefs after Teaching Practice}

The initial analyses showed that the student teachers mainly endorsed constructivist beliefs. The mean scores of student teachers' constructivist beliefs were ranged from 3.43 to 3.61 in the 4 point scale. In order to assess the changes of beliefs across the student teaching experience, Paired t-tests were used. The t-test scores and sample means were displayed in Table 2, which showed statistically significant changes in total and constructivist scales. The result of the t-test on the TBS Total scores illustrated a statistically significant increase in the post-test. Analysis of the constructivist scale for the pre and post test scores revealed that the student teachers' post test scores were significantly higher than their pre-test scores $\left(\mathrm{t}_{74}=-3.53 ; \mathrm{p}<0.05\right)$. On the other hand, comparison of the scores on the traditional scale indicated that the means of pre and post test scores were non-significant.

Table 2. Pre and Post-test Scores of Student Teachers

\begin{tabular}{ccccccccc}
\hline & \multicolumn{3}{c}{ Pre-test } & \multicolumn{7}{c}{ Post-test } \\
\cline { 2 - 9 } Constructivist & $\mathrm{n}$ & $\mathrm{M}$ & $\mathrm{SD}$ & $\mathrm{n}$ & $\mathrm{M}$ & $\mathrm{SD}$ & $\mathrm{t}$ & $\mathrm{p}$ \\
\cline { 2 - 9 } Traditional & 75 & 2.43 & .26 & 75 & 3.61 & .26 & -3.53 & .001 \\
Total & 75 & 3.01 & .21 & 75 & 3.21 & .21 & -4.87 & .000 \\
\hline
\end{tabular}

Note: Items on the traditional scale were reverse coded 
Differences between Instructional Beliefs of Student Teachers and Cooperating Teachers

To examine the differences between the instructional beliefs of student teachers and cooperating teachers, independent t-tests were conducted. The student teachers' pre and post test scores were compared to the scores of cooperating teachers (Table 3 ).

Table 3. Student Teachers' and Cooperating Teachers' Beliefs

\begin{tabular}{ccccccccc}
\hline & \multicolumn{3}{c}{ Student Teachers } & \multicolumn{5}{c}{ Cooperating Teachers } \\
\cline { 2 - 9 } & $\mathrm{n}$ & $\mathrm{M}$ & $\mathrm{SD}$ & $\mathrm{n}$ & $\mathrm{M}$ & $\mathrm{SD}$ & $\mathrm{t}$ & $\mathrm{p}$ \\
\cline { 2 - 9 } Pre-test total & 75 & 3.01 & .25 & 35 & 2.79 & .27 & 4.20 & .000 \\
Pre-test constructivist & 75 & 3.43 & .37 & 35 & 3.35 & .42 & 0.98 & .327 \\
Pre-test traditional & 75 & 2.60 & .30 & 35 & 2.22 & .39 & 5,44 & .000 \\
Post-test total & 75 & 3.21 & .21 & 35 & 2.79 & .27 & 8,69 & .000 \\
Posttest constructivist & 75 & 3.61 & .26 & 35 & 3.35 & .42 & 3.93 & .000 \\
Posttest traditional & 75 & 2.62 & .32 & 35 & 2.22 & .39 & 5.55 & .000 \\
\hline
\end{tabular}

Note: Items on the traditional scale were reverse coded

Pre-test results indicated that the statistically significant differences between the student teachers' and cooperating teachers' instructional beliefs were found on the traditional scale and total scores. There were no statistically significant differences between student teachers and cooperating teachers' instructional beliefs on the constructivist scale. The cooperating teachers scored higher on traditional scale. It can be concluded that cooperating teachers hold more traditional instructional beliefs than student teachers.

After the 15-week student teaching experience, post tests were administered to the student teachers. Analysis of the post test scores indicated that there were statistically significant differences between student teachers and cooperating teachers' beliefs on both traditional and constructivist scales. The t-test for the constructivist scale means indicated that the student teachers endorsed constructive beliefs at a higher level than the cooperating teachers. On the traditional scale the cooperating teachers valued traditional beliefs higher than the student teacher group. Comparisons of the pre and post test scores to the cooperating teacher scores showed that over the course of student teaching the student teachers constructivist beliefs increased in spite of socializing with more traditional teachers.

\section{Discussion and Implications}

Results for this study show that student teaching course had significant effects on student teachers' instructional beliefs. This study looks closely at whether student teaching experiences change constructivist and traditional instructional beliefs. It finds that student teachers' constructivist beliefs exhibited change during the student teaching period. This finding is consistent with some of the prior studies (Lin, et al., 2001; Nettle, 1998; Wooley et al., 1999) which claim student teachers beliefs may change during student 
teaching. Examination of these changes indicates that the participant students often maintain and develop constructivist beliefs. In other words, student teachers' constructivist beliefs significantly increased after completing the student teaching period. Factors contributing to this change might be the construction of the student teaching course which constantly support and promote constructivist teaching strategies. Another explanation for increase in the constructivist beliefs might be related to the actual experiences with working with young children. Lin et al., (2001) find that experience in working with young children is illustrated as one of the strong factors to generate change in teachers' beliefs. Su (1992) also show that student teaching and students in the practice schools demonstrated more influence than college course work. Hopefully, this result suggests that student teaching make positive contributions on constructivist beliefs of student teachers. On the other hand, the results of this study also show that student teachers' traditional beliefs remain stable over the course of student teaching. It is possible to claim that student teaching course is tailored to persuade student teachers to embrace constructivist teaching and nothing is planned to diminish their traditional beliefs. Joram and Gabriele (1998) find that previously held traditional beliefs are difficult to change and need to be specifically targeted.

Results further revealed that there is a statistically significant difference between the student teachers' and cooperating teachers' instructional beliefs. It is notable that the cooperating teachers hold more traditional beliefs than student teachers. The student teachers' traditional beliefs do not tend to increase while they are working with cooperating teachers who value more traditional beliefs. This finding indicated that the student teaching experience is very important in shaping a student teacher's beliefs. Even when student teachers collaborate with teachers with more traditional beliefs, they retain and increase their constructivist beliefs at the end of the student teaching.

The findings of this study are particularly significant in restating the importance of student teaching experience. Unfortunately, student teaching experience was not valued as an important activity either in placement schools or universities (Tang, 2003). Student teaching provides a unique opportunity for both developing teaching skills and constructing instructional beliefs. The results of this study suggested that a student teaching course with a strong emphasis on constructivist instructional beliefs could be effective in promoting belief changes in favor of constructivism. Considering the fact that, some student teachers placed into classrooms in which teachers use the combinations of constructivist and traditional instructional techniques (Vartuli, 1999).

For this reason, teacher education programs should view student teaching course as an opportunity to enhance student teachers' constructivist beliefs. The process of the student teaching course should also be tailored to promote constructivist, child-centered beliefs and practices. It is also important to keep in mind that this process is largely influenced by the responsibilities and support of the university supervisor and cooperating teachers. Their supports such as giving feedback after observations, encouraging students thought processes through reflection and collegial discussions (Edwards \& Protheroe, 
2003) is necessary for successful student teaching experiences. Moreover, modeling and encouraging student teachers to take risks were among the suggested support systems for the university supervisor and cooperating teachers.

In conclusion, the student teaching experience with its focus on encouraging student teachers to adopt constructivist beliefs has helped them to retain and promote their constructivist beliefs. Future studies should also investigate how these changed beliefs influenced actual practices of student teachers when they received a teaching appointment. Examining the long-term effects of these changes may provide valuable insights for teacher education programs.

\section{Acknowledgment}

I gratefully acknowledge financial support from Pamukkale University Scientific Research Center as part of research project numbered 2014KKP034.

\section{References}

Bandura, A. (1986). Social foundations of thought and action: A social cognitive theory. Englewood Cliffs, NJ: Prentice-Hall.

Brownlee, J., Purdie, N., \& Boulton-Lewis, G. (2001). Changing Epistemological Beliefs in Pre-service Teacher Education Students. Teaching in Higher Education, 6 (2), 247-268.

Buchanan, T. K., Burts, D. C., Bidner, J., White, V. Y., \& Charlesworth, R. (1998). Predictors of the developmental appropriateness of the beliefs and practice $\mathrm{s}$ of first, second and third grade teachers. Early Childhood Research Quarterly, 13(3), 459-483.

Caires, S., \& Almeida, L.S. (2005). Teaching practice in Initial Teacher Education: İts impact on student teachers' professional skills and development. Journal of Education for Teaching. 31(2), 111-120.

Cohen, A. S., Peters, D. L., \& Willis, S. L. (1976). The effects of early childhood education student teaching on program preferences, beliefs and behaviors. Educational Research.70 (1), 15-20.

Cummmins, C.L., Cheek, E.H., \& Lidsey, J.D. (2004). The relationship between teachers' literacy beliefs and their instructional practices: A brief review of the literature for teacher educators. E Journal of teaching and learning in diverse settings, 1(2) 75-188.

DiPietro, K. (2004). The Effects of a Constructivist Intervention on Pre-Service Teachers. Educational Technology \& Society, 7 (1), 63-77.

Edwards, A., \& Protheroe, L., (2003). Learning to See in Classrooms: what are student teachers learning about teaching and learning while learning to teach in schools? British Educational Research Journal, 29 (2), 227-242

Fang, Z. (1996). A review of research on teacher beliefs and practices. Educational research, 38(1), 47-65 
File, N. \& Gullo, D.E. (2002). A comparison of early childhood and elementary education students' beliefs about primary classroom teaching practices. Early childhood research quarterly. 17,126-137

Hascher, T., Cocard, Y., \& Moser, P. (2004). Forget about theory - practice is all? Student teachers' learning in practicum. Teachers and Teaching: Theory and Practice, 10 (6), 623-637.

Isikoglu, N. (2008).The Effects of a Teaching Methods Course on Early Childhood Preservice Teachers' Beliefs. Journal of Early Childhood Teacher Education, 29:3,190 - 203 doi: 10.1080/10901020802275260

Joram, E., \& Gabriele, A. J. (1998). Preservice teachers' prior beliefs: Transforming Obstacles into opportunities. Teaching and Teacher Education. 14 (2), 175-191.

Kagan, D.M. (1992). Implications of Research on Teacher Belief. Educational Psychologist, 27 (1), 65-90.

Lin, H., Hazareesingh, N., Taylor, J., Gorrell, J., \& Carlson, H.L. (2001). Early childhood and elementary preservice teachers' beliefs. Journal of Early Childhood Teacher Education. 22, 135-150.

MEB (2012).MEB Okul Öncesi Eğitimi Programı Aylık Eğitim Planı Formatı. Retrieved from ttkb.meb.gov.tr/

Nettle, E. B. (1998). Stability and change in the beliefs of student teachers during practice teaching. Teaching and Teacher Education, 14 (2), 193-204.

Pajares, M.F. (1992). Teachers' beliefs and educational research: cleaning up a messy construct. Review of educational research, 62 (3), 307-332

Pankratius, W. J., \& Young, M. W. (1995). Perspectives on education: A constructivist approach to an introductory course. Education, 115 (3), 363-370.

Richardson, V. (1996). The role of attitudes and beliefs in learning to teach. In J. Sikula (Ed.), Handbook of research on teaching (pp.376-391). New York: Macmillian.

Ronfeldt, M. \& Reininger, M. (2012). More or better student teaching? Teaching and Teacher Education. 28, 1091-1106. Retrieved from http://dx.doi.org/10.1016/j.ta te.2012.06.003

Rozelle, J.J., \& Wilson, S. M.(2012). Opening the black box of field experiences: How cooperating teachers' beliefs and practice shape student teachers' beliefs and practices. Teaching and Teacher Education, 28, 1196-1205. Retrieved from http://dx.doi.org/10.1016/j.tate.2012.07.008

Scott-Little, C., La Paro, K. M., \& Weisner, A. (2006). Examining Differences in Students' Beliefs and Attitudes: An Important Element of Performance-Based Assessment Systems for Teacher Preparation Programs. Journal of Early Childhood Teacher Education, 27, 379-390. doi: 10.1080/10901020600996273

Smith, K.E. (1997). Student teachers' beliefs about developmentally appropriate Practice: Pattern, stability and the influence of locus control. Early Childhood Research Quarterly, 12. 221-243.

Smith, J.D. (2005). Understanding the beliefs, concerns and priorities of trainee teachers: a multidisciplinary approach. Mentoring and Tutoring. 13 (2) 205-219.

$\mathrm{Su}, \mathrm{Z}$. X ( 1992). Sources of influence in preservice teacher socialization. Journal of Education for Teaching. 18 (3). 239-258. doi:10.1080/0260747920180303.

Tang, S. Y. F. (2003). Challenge and support: the dynamics of student teachers' professional learning in the field experience. Teaching and Teacher Education, 19 (5), 483-498.doi:10.1016/S0742-05X(03)00047-7

Trivette, C. M., Dunst, C. J., Hamby, D. W., \& Meter, D. (2012), Relationship Between Early Childhood Practitioner Beliefs and the Adoption of Innovative 
and Recommended Practices. Research Brief, 6(1)1-9. Retrieved from Tots-nTech Institute: http://www.tnt.asu

Vartuli, S. (1999). How Early Childhood Teacher Beliefs Vary Across Grade Level. Early Childhood Research Quarterly, 14 (4), 489-514.

Wooley, S.L., Wooley, A.W. \& Hosey, M. (1999). Impact of student teaching on student teachers' beliefs related to behaviorist and constructivist theories of learning. Paper presented at the annual meeting of the association of teacher educators. Chicago, IL 